\title{
Mitä kansalais- ja työväenopistot odottavat tutkimukselta
}

Aluksi pari sanaa taustaksi kansalais- ja työväenopistojen viime vuosien kehityksestä. Opistoihin on saatu kolmen viimeisen vuoden aikana noin 300 uutta päätoimista opettajaa. Yhteensä heitä on jo yli 650 henkeä. Myös tilat ja välineet ovat kohentuneet monissa opistoissa. Voidaankin todeta, että maassa on joukko opistoja, joiden resurssitilanne on jo varsin hyvä. Tämä ei kuitenkaan koske kaikkia opistoja, vaan valtaosa opistoista on edelleen alkuvaiheessa resurssikehityksessään. Tyydyttävän tilanteen aikaansaamisessa riittää vielä pitkäksi aikaa työtä.

Mutta hyvin varustetuissa opistoissa olemme nyt uudessa tilanteessa, sillä opetuksen tason kohottamisessa keskeistä ei enää voi olla pyrkimys resurssien lisäämiseen. Kiinnittämällä huomio ainoastaan resursseihin ei enää ole odotettavissa mitään merkittävää laadullista parannusta opetuksen tasossa. Mihin huomio sitten tulisi jatkossa kiinnittää? Mitä opetuksen tason parantamiseksi tulisi tässä uudessa tilanteessa tehdä?

Vastaus on selvä. Meidän on ryhdyttävä kehittämään opetusmenetelmiä. Nyt on pakko lopultakin katsoa, mitä opintoryhmissä oikeastaan tapahtuu. On kysyttävä, mitä näillä kaikilla hienoilla resursseilla aiotaan tehdä. Päädymme näin vaikeimman asian äärelle: meidän on ryhdyttävä etsimään entistä parempia didaktisia ratkaisuja. Samalla meidän on kysyttävä itseltämme: mitä me itse asiassa tiedämme aikuisdidaktiikasta ja laajemmin koko aikuiskasvatuksesta.
Tästä seuraa mielestäni kolme tehtävää, joista me emme selviä ilman tutkimusta.

Ensimmäinen on vapaan sivistystyön itseymmärryksen lisääminen omasta asemastaan ja tehtävästään aikuiskasvatuksen kentässä. Olisi selvitettävä, missä määrin vapaa sivistystyö voi edelleen nojautua klassiseen sivistysihanteeseensa ja missä suhteessa se pitäisi korvata jollakin uudella. Mikä tämä uusi sivistysnäkemys voisi olla? Olen varma, että jos opistojen rehtoreilta tiedusteltaisiin, mitä he ymmärtävät vapaalla sivistystyöllä tänä päivänä, vastaukset muodostaisivat todella laajan kirjon, eikä niissä välttämättä selvin yhteinen nimittäjä olisi vapaan sivistystyön perinteinen sivistyskäsitys. Jos käsitykset vapaan sivistystyön luonteesta ja tehtävistä poikkeavat toisistaan, ei ole ihmeellistä, että myös käytännön toiminnassa esiintyy jopa ristiriitaisia ajatuksia siitä, mitä kaikkia tehtäviä kansalaisopistojen tulisi hoitaa. Eräs ilmentymä tästä on se, että opistot ovat valmiita kritiikittömästi hyväksymään minkä tahansa uuden tehtäväksiannon, mitä niille satutaan tuputtamaan ulkoapäin.

Toinen tehtävä on opistoissa käytettävien työmuotojen kehittäminen. Opistojen opetuksessa yhdistyy tällä hetkellä kaksi piirrettä. Toisaalta suurin osa opetusmenetelmistä periytyy ties kuinka kaukaa, toisaalta säännöllisen aaltoliikkeen tavoin ilmaantuu uusia, muodinmukaisia menetelmiä, jotka saavat meidän sokean ihastuksemme osakseen. Vanhat menetelmät eivät kehity mihinkään ja uusista ei jää käteen mitään ennen kuin jo toinen muoti vaatii 
huomiomme osakseen. Nämä molemmat kehityspiirteet ovat mielestäni seurausta siitä, että meiltä puuttuu pitkäjänteinen aikuisdidaktiikan kokeilu- ja tutkimustoiminta. Meillä ei ole teoreettista valmiutta sen enempää vanhojen menetelmien kehittämiseksi kuin uusien menetelmien arvon punnitsemiseksi.

Tämän vuoksi olisikin käynnistettävä tieteelliseltä pohjalta monimuotoisten ainedidaktisten kokeilujen ja tutkimusten sarja, jotta teoreettinen tietämyksemme aikuisopetukseen soveltuvista menetelmistä lisääntyisi. Vasta tällaisen tietämyksen pohjalle me voimme luoda kestävän opettajakoulutusjärjestelmän.

Kokeilu- ja tutkimusprojektien tulisi tapahtua kiinteässä yhteydessä yliopistojen tieteellisiin laitoksiin, jotta projektien tieteellinen taso turvattaisiin. Niiden tulisi myös olla riittävän pitkäaikaisia, jotta kokeiluista ehtisi muodostua perusta jatkuvalle opetusmenetelmien tutkimus- ja kehittämistyölle. Päämääränä pitäisi olla tilanne, jossa meillä itsellämme opistoissa on jatkuvasti valmiudet arvioida, mikä kunkin alan opetussisällöissä on olennaista ja mikä epäolennaista, miten tämä olennainen voitaisiin parhaiten opettaa opiskelijoille, ja miten oppimistuloksia pitäisi arvioida.

Kolmannen tehtävän taustalla on lähestyvä henkilökohtainen tragedia. Tätä voidaan kutsua esim. rämettymiseksi. Havaintojeni mukaan tämä ilmiö uhkaa käytännön tehtävissä noin kymmenen vuotta työskennelleitä. Se ilmenee ennen kaikkea siinä, että kiinnostus oman työn kehittämistä kohtaan heikkenee ja lakkaa lopulta kokonaan. Työtä tehdään siksi, että siitä saadaan palkkaa. Rutiinit toteutetaan vuodesta toiseen samanlaisina. Käsitteet alkavat seota ja ajatukset puuroutua. Teoria alkaa naurattaa. Tutkimuksella ei tunnu olevan mitään annettavaa. Kymmenen vuotta käytäntöä riittää nujertamaan kenet tahansa.

Ennen kuin tähän pisteeseen joudutaan, pitäisi mahdollisimman monelle käytännön tehtävissä toimivalle järjestää jonkinlainen mahdollisuus tieteellisiin täydennysopintoihin. Olisi saatava aikaan projekteja, joissa käytännön työtehtävissä toimivat saataisiin tutkimaan oman työnsä kehittämistä. Aluksi kiinnostuksen suuntana tällaisessa tutkivassa työn kehittämisessä olisi varmastikin käytäntö, mutta pitempään jatkuessaan se olisi omiaan luomaan perustaa myös oikeille tieteeilisille jatko-opinnoille. Vain hyvin harvoilla riittää energiaa ponnistaa suoraan käytännöstä lisensiaattiseminaareihin. Jälleen korostan sitä, että näidenkin projektien tulee olla riittävän pitkäaikaisia, jotta niistä voisi tulla aitoja oppimisprosesseja niihin osallistuville. Ja jotta pohdinnoilla olisi muutakin kuin vain terapeuttista merkitystä, tulisi projektien toimia kiinteässä yhteydessä tieteellisiin laitoksiin.

Sen verran olen näistä ajatuksista keskustellut kollegojeni kanssa, että tiedän samantapaisten ajatusten askarruttavan muitakin kuin minua. Kenttä on siis huutanut. Aika näyttää, miten tutkimus vastaa. 